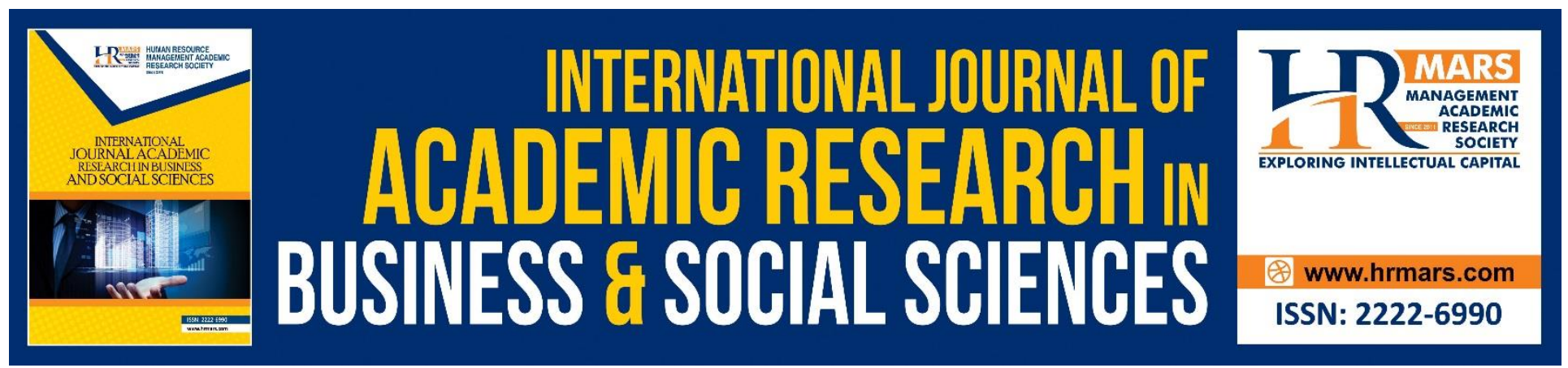

\title{
Consumer Awareness of Using Eco-friendly Packaging Product Among Generation X in Kota Bharu, Kelantan
}

\author{
Nik Noorhazila Nik Mud, Aimi Nadia Ibrahim @ Zakaria, Nur Ain Mahat, \\ Mardhiah Kamaruddin
}

To Link this Article: http://dx.doi.org/10.6007/IJARBSS/v8-i9/4856

DOI: $\quad 10.6007 /$ IJARBSS/v8-i9/4856

Received: 21 August 2018, Revised: 16 Sept 2018, Accepted: 10 Oct 2018

Published Online: 15 Oct 2018

In-Text Citation: (Mud, Zakaria, Mahat, \& Kamaruddin, 2018)

To Cite this Article: Mud, N. N. N., Zakaria, A. N. I. @, Mahat, N. A., \& Kamaruddin, M. (2018). Consumer Awareness of Using Eco-friendly Packaging Product Among Generation X in Kota Bharu, Kelantan. International Journal of Academic Research in Business and Social Sciences, 8(9), 1463-1472.

Copyright: (C) 2018 The Author(s)

Published by Human Resource Management Academic Research Society (www.hrmars.com)

This article is published under the Creative Commons Attribution (CC BY 4.0) license. Anyone may reproduce, distribute, translate and create derivative works of this article (for both commercial and non-commercial purposes), subject to full attribution to the original publication and authors. The full terms of this license may be seen

at: http://creativecommons.org/licences/by/4.0/legalcode

Vol. 8, No. 9, September 2018, Pg. 1463 - 1472

http://hrmars.com/index.php/pages/detail/IJARBSS

JOURNAL HOMEPAGE

Full Terms \& Conditions of access and use can be found at http://hrmars.com/index.php/pages/detail/publication-ethics 


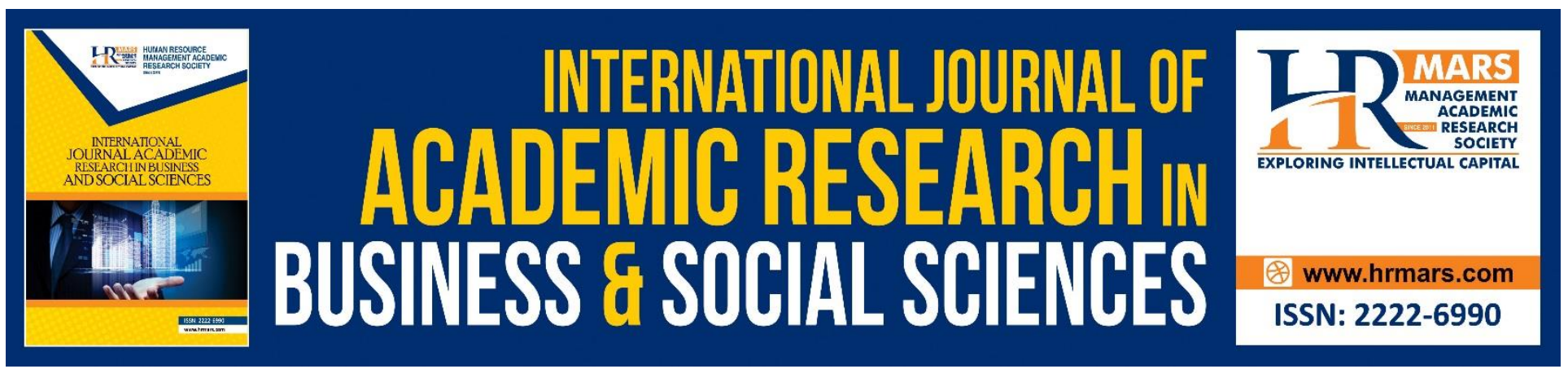

\title{
Consumer Awareness of Using Eco-friendly Packaging Product Among Generation X in Kota Bharu, Kelantan
}

\author{
Nik Noorhazila Nik Mud \\ Universiti Malaysia Kelantan, Malaysia \\ Aimi Nadia Ibrahim @ Zakaria \\ Universiti Malaysia Kelantan, Malaysia \\ Nur Ain Mahat \\ Universiti Malaysia Kelantan, Malaysia \\ Mardhiah Kamaruddin \\ Universiti Malaysia Kelantan, Malaysia
}

\begin{abstract}
Environmentally friendly or also referred to an eco-friendly is one of the strategies used by many retail industries in order to produce goods or services that not harmful to the earth or environment. The study is aimed to identify which factors (material, price, colour and knowledge) significant to influence the awareness of using eco-friendly packaging product among Generation X in Kota Bharu, Kelantan. Descriptive survey design was adopted and convenience sampling technique was used to obtain a sample of 384 respondents among generation X between the ages of 37 to 56 years old. Data were collected through questionnaires and analyzed on a 5 point Likert Scale was distributed to generation $\mathrm{X}$ in Kota Bharu. The result revealed that material, price, colour and knowledge have positive relationship towards consumer awareness of using eco-friendly packaging products. This study shows that all the factors have significant influence awareness of using eco-friendly packaging product among Generation X in Kota Bharu, Kelantan.
\end{abstract}

\section{Introduction}

Nowadays, the green product has become a major trend in green marketing product in our business world but this trend is still new in Asian countries especially for Malaysia (Albert Lasuin \& Yuen Ching, 2014). Therefore, to be revealed as the concept of "Green Marketing" , the factors that affected it is 
mostly giving harm to the environment such global warming, threatening the future of human being, the growth of population and exhaustion of natural resources (Yakup \& Sevil, 2011). Noor and Muhammad (2012) stated the power of purchasing by Asian countries and the rapid growth of the awareness of environmental has become the primary target market by the international marketers. Besides that, due to the issues of increasing on awareness of environmental, the practice and behaviour of consumers has been changed as well as in the marketplace and industry in production (Barber, Kuo, Bishop, \& Goodman, 2012).

According to UNESCO Institute for Statistics, the population in Malaysia is increasing from 1951 to 2017. An increasing in this population then will lead to demand for all consumer goods will also increase and may increase the quantity of waste that makes in residential, educational institutions, hospitals, hotels and everywhere else (Fatima, n.d.). Each year more than 140 million tons plastics are manufactured throughout the world. In many countries, plastics are disposed of through open burning and landfilling. Open burning and landfilling releases chemical pollutants into the air and land. It causes chemical pollutants spread globally and possible cause various health problems (Kumar et al., 2014) .Therefore, this study will be conducted to determine factors that influence the awareness of using eco-friendly packaging product. So that the solution that has been made from this study can be an important role in avoiding the destructive effects and factors for the environment.

\section{Research Objective}

To identify which factors influence consumer awareness of using eco-friendly packaging products among Generation X in Kota Bharu, Kelantan.

\section{Research Question}

The research question posed for this study is:

What are the factors influence consumer awareness of using eco-friendly packaging products among Generation X in Kota Bharu, Kelantan.

\section{Hypothesis}

One null hypothesis is formulated for this study at 0.05 level of significance.

Hypothesis 1: Product packing material and consumer awareness of using eco-friendly packaging product.

$\mathrm{H}_{0}$ : There is no significant relationship between material of product packaging and consumer consumer awareness of using eco-friendly packaging product.

$\mathrm{H}_{1}$ : There is a significant relationship between material of product packaging and consumer awareness of using eco-friendly packaging product. 
INTERNATIONAL JOURNAL OF ACADEMIC RESEARCH IN BUSINESS AND SOCIAL SCIENCES

Vol. 8, No. 9, Sept. 2018, E-ISSN: 2222-6990 (C) 2018 HRMARS

Hypothesis 2: Price and consumer awareness of using eco-friendly packaging product.

$\mathrm{H}_{0}$ : There is no significant relationship between price and consumer awareness of using eco-friendly packaging product.

$\mathrm{H}_{1}$ : There is a significant relationship between price and consumer awareness of using eco-friendly packaging product.

Hypothesis 3: Colour and consumer awareness of using eco-friendly packaging product.

$\mathrm{H}_{0}$ : There is no significant relationship between colour and consumer awareness of using eco-friendly packaging product.

$\mathrm{H}_{1}$ : There is a significant relationship between colour and consumer awareness of using eco-friendly packaging product.

Hypothesis 4: Knowledge about eco-friendly and consumer awareness of using eco-friendly packaging product.

$\mathrm{H}_{0}$ : There is no significant relationship between knowledge about eco-friendly and consumer awareness of using eco-friendly packaging product.

$\mathrm{H}_{1}$ : There is a significant relationship between knowledge about eco-friendly and consumer awareness of using eco-friendly packaging product.

Based on literature review, a proposed conceptual framework in figure 1 formed in order to identify the relationship between the factors that influence consumer awareness of using eco-friendly packaging products among Generation X in Kota Bharu, Kelantan. The independent variables for this study were product packaging material, price, colour and knowledge about eco-friendly. All these variables will be studied as the independent variables. The dependent variable is consumer awareness using eco-friendly packaging product.

\section{Research Methodology}

Descriptive survey design was adopted and convenience sampling technique was used to obtain a sample of 384 respondents among generation X between the ages of 37 to 56 years old. The population of the study was made up of all population in Kota Bharu, totaling 371,400 .

A five-item structured questionnaire was developed to identify the relationship between dependent and independent variables in this study. Thereafter it was tested for reliability using Cronbach Alpha method and a coefficient of 0.94 was obtained and was considered high and taken to be reliable. Data were gathered through the use of structured questionnaire specifically designed to elicit information needed for the study and were analysed using frequency tables, t-test and Pearson Product Moment Correlation. The hypothesis was tested using independent t-test statistics at 0.05 level of significance. 
INTERNATIONAL JOURNAL OF ACADEMIC RESEARCH IN BUSINESS AND SOCIAL SCIENCES Vol. 8, No. 9, Sept. 2018, E-ISSN: 2222-6990 @ 2018 HRMARS

\section{Results and Discussion of Findings}

The results of the data analysis was presented in tables according to the research question and hypothesis.

\section{Results of the Pearson Correlation Analysis}

Table 1. Correlations between Material of Product Packaging and Consumer Awareness

\begin{tabular}{|c|l|c|c|}
\hline & & Consumer Awareness & Materials \\
\hline Consumer Awareness & Pearson correlation & 1 & $0.74^{* *}$ \\
& Sig . (2-tailed) & & 0.00 \\
& $\mathrm{~N}$ & 384 & 384 \\
\hline Materials & Pearson correlation & $0.74^{* *}$ & 1 \\
& Sig . (2-tailed) & 0.00 & 384 \\
\hline
\end{tabular}

** Correlation is significant at the 0.001 level (2-tailed)

Table 2 . Correlations between Price of Product Packaging and Consumer Awareness

\begin{tabular}{|c|l|c|c|}
\hline & & Consumer Awareness & Price \\
\hline Consumer Awareness & Pearson correlation & 1 & $0.81^{* *}$ \\
& Sig . (2-tailed) & & 0.00 \\
& $\mathrm{~N}$ & 384 & 384 \\
\hline Price & Pearson correlation & $0.81^{* *}$ & 1 \\
& Sig . (2-tailed) & 0.00 & 384 \\
\hline
\end{tabular}

** Correlation is significant at the 0.001 level (2-tailed)

Table 3 . Correlations between Colour of Product Packaging and Consumer Awareness

\begin{tabular}{|c|l|c|c|}
\hline & & Consumer Awareness & Colour \\
\hline Consumer Awareness & Pearson correlation & 1 & $0.73^{* *}$ \\
& Sig . (2-tailed) & & 0.00 \\
& $\mathrm{~N}$ & 384 & 384 \\
\hline Colour & Pearson correlation & $0.73^{* *}$ & 1 \\
& Sig . (2-tailed) & 0.00 & 384 \\
\hline
\end{tabular}

** Correlation is significant at the 0.001 level (2-tailed) 
INTERNATIONAL JOURNAL OF ACADEMIC RESEARCH IN BUSINESS AND SOCIAL SCIENCES Vol. 8, No. 9, Sept. 2018, E-ISSN: 2222-6990 @ 2018 HRMARS

Table 4 . Correlations Knowledge of Product Packaging and Consumer Awareness

\begin{tabular}{|c|l|c|c|}
\hline & & Consumer Awareness & Knowledge \\
\hline Consumer Awareness & Pearson correlation & 1 & $0.66^{* *}$ \\
& Sig . (2-tailed) & & .000 \\
& $\mathrm{~N}$ & 384 & 384 \\
\hline Knowledge & Pearson correlation & $0.66^{* *}$ & 1 \\
& Sig . (2-tailed) & 0.00 & \\
& $\mathrm{~N}$ & 384 & 384 \\
\hline
\end{tabular}

** Correlation is significant at the 0.001 level (2-tailed)

\section{Hypothesis Testing}

Table 1 shown the correlation between the independent variables and dependent variable. The results showed that there was a significant relationship between material of product packaging and consumer awareness of using eco-friendly packaging product. $(p<0.001, r=0.74)$ indicating moderate to good correlation between the variables since $p<0.001$, the research has rejected the null hypothesis and accept the alternative hypothesis.

$\mathrm{H} 1$ : There is a significant relationship between material of product packaging and consumer awareness of using eco-friendly packaging product.

Table 2 shown the correlation between the independent variables and dependent variable. The results showed that there was a significant relationship between price and consumer awareness of using eco-friendly packaging product $(p<0.001, r=0.81)$ indicating perfect correlation between the variables since $p<0.001$, the research has rejected the null hypothesis and accept the alternative hypothesis.

$\mathrm{H} 1$ : There is a significant relationship between price and consumer awareness of using eco-friendly packaging product.

Table 3 shown the correlation between the independent variables and dependent variable. The results showed that there was a significant relationship between colour and consumer awareness of using eco-friendly packaging product $(p<0.001, r=0.73)$ indicating moderate to good correlation between the variables since $p<0.001$, the research has rejected the null hypothesis and accept the alternative hypothesis.

$\mathrm{H} 1$ : There is a significant relationship between colour and consumer awareness of using eco-friendly packaging product.

Table 4 shown the correlation between the independent variables and dependent variable. The results showed that there was a significant relationship between knowledge about eco-friendly and consumer awareness of using eco-friendly packaging product $(p<0.001, r=0.66)$ indicating 
INTERNATIONAL JOURNAL OF ACADEMIC RESEARCH IN BUSINESS AND SOCIAL SCIENCES

Vol. 8, No. 9, Sept. 2018, E-ISSN: 2222-6990 @ 2018 HRMARS

moderate to good correlation between the variables since $p<0.001$, the research has rejected the null hypothesis and accept the alternative hypothesis.

H1: There is a significant relationship between knowledge about eco-friendly and consumer awareness of using eco-friendly packaging product.

\section{Discussion of Findings}

\section{Material of Packaging Product}

From the research finding, it is shown that Hypothesis $\left(\mathrm{H}_{1}\right)$ was accepted as there was a significant relationship between material of product packaging and consumer awareness of using eco-friendly packaging product. This is supported by Raja Kumar Kathiravelu et al., (2014), the company usually will have several materials for the respondent regarding the products packaging including the cardboard packaging, glass packaging, and plastic packaging. Thus, these types of material have the respondent own advantage and disadvantages. There was an exceptional value of using wood as the material for the packaging (Salahshour \& Feiz ,2009). Glass packaging is appropriate for fluid products (Babalis et al., 2013). The consumers' buying behaviour also was greatly affected by the material of the product packaging (Jusup Zekiri \& Vjollca Visoka, 2015). Thus, material applications play a crucial role in product packaging.

\section{Price of the packaging product}

In the study, it prescribes that there is strong positive relationship exists between price of eco-friendly packaging product and consumer awareness of using eco-friendly packaging product. From the research, based on the Pearson Correlation result, it shows that the $r$-value is 0.81 with $p$ value at 0.000 at significant level less than 0.05 . Hypothesis $\left(H_{1}\right)$ was accepted as there was a significant relationship between price of eco-friendly packaging product and consumer awareness of using eco-friendly packaging product.. This is supported Kent \& Omar (2003)price is one of the important factor while doing purchasing of a products. It is one of the crucial part to be chosen at first when a customer making decision to buy products. From the finding, respondent it may be seen that the value of the price for the goods and services will attract the consumers to make a purchase. Price also considered as an important indicator which is it could affect the consumer's decision when making purchasing. This is because the eco-friendly packaging product is a long-term used among Generation X. Besides, according to the researcher D'Souza et al. (2006), price play a vital consideration in purchasing, it is one of the elements that the consumers make when purchase a sustainable goods. The price factors also supported by Jensen \& Coelho (2011) stated that price have the strong relationship with the awareness of using eco-friendly packaging products based on their research study.

\section{Colour of Product Packaging}

Based on the interpretation of results, it addresses that hypothesis $\left(\mathrm{H}_{1}\right)$ was accepted as there was a significant relationship between colour and consumer awareness of using eco-friendly packaging product. The effects of colour fit on consumer perception of recyclable of product packaging have been accepted as the factor influence consumer awareness of product packaging. 
INTERNATIONAL JOURNAL OF ACADEMIC RESEARCH IN BUSINESS AND SOCIAL SCIENCES Vol. 8, No. 9, Sept. 2018, E-ISSN: 2222-6990 (C) 2018 HRMARS

The colour and type of product packaging influences the attractiveness and harmonization of packaging by consumers (Ting Wei et al.,2014).

\section{Knowledge about eco-friendly packaging product}

Regarding to the knowledge about eco-friendly packaging product, it is shown that Hypothesis $\left(\mathrm{H}_{1}\right)$ was accepted as there was a significant relationship between knowledge of product packaging and consumer awareness of using eco-friendly packaging product. It is mean that the the knowledge is an important factor to be considered in order to create awareness among the consumer. Having knowledge about an eco-friendly will prevent the consumers to do anything regarding the environmental harming. Thus, the consumer will be more aware and support the using of an ecofriendly packaging product. This finding supported by Kumar, P. K., \& Anand, B. (2013), the negative consumer perception and lack about green product can be resolved by educating and build a better product respectively. All schools need to be compulsory to teach a deeper knowledge and understanding about environmental education to all students in order to create awareness, transmit information and developing habits. There are environmental education in school curriculum but it is not being implemented effectively (Kimaryo, 2011).

\section{Conclusion and Recommendations}

Based on the findings of the study, the following recommendations were made:

i. The marketers of the industry should not consider the packaging is the only factor for the success of any product. The respondent should also take up other important factors of the marketing while the respondent are launching new products or revitalize old products. It is also recommended to other researchers when the respondent take up packaging then the respondent should also consider other factors and dimensions of marketing as well.

ii. Generation X should be educated about environmental friendly so that the respondent will be aware about it. The knowledge about environmental friendly is important because it will inform the consumer about what type of packaging that can harm the environment. The researcher recommended for the respondent to implement the respondent buying behaviour of eco-friendly products not only for the respondent but share it among the co-workers.

iii. Future researcher should conducts research by using the online survey not only for Generation $X$ but also can extending the survey to people in all the type of generation. This is because each of this age group might have different behaviour and perception toward the eco-friendly product packaging.

\section{Corresponding Author}

Nik Noorhazila Binti Nik Mud, Universiti Malaysia Kelantan, Malaysia

Email: noorhazila.nm@umk.edu.my, Universiti Malaysia Kelantan, Karung Berkunci 36, Taman

Bendahara, 16100 Kota Bharu, Kelantan. 
INTERNATIONAL JOURNAL OF ACADEMIC RESEARCH IN BUSINESS AND SOCIAL SCIENCES

Vol. 8, No. 9, Sept. 2018, E-ISSN: 2222-6990 @ 2018 HRMARS

\section{References}

Akeiber, H., Nejat, P., Majid, M. Z. A., Wahid, M. A., Jomehzadeh, F., Famileh, I. Z., \& Zaki, S. A. (2016). A review on phase change material (PCM) for sustainable passive cooling in building envelopes. Renewable and Sustainable Energy Reviews, 60, 1470-149

Albert Lasuin, C., \& Yuen Ching, N. (2014). Factors Influencing Green Purchase Intention among University Students. Malaysian Journal of Business and Economics (Vol. 1). Online. Retrieved from http://www.ums.edu.my/mjbe/images/mjbe/vol1/number2/Complete (Including Cover).pdf

Athanasios Babalis, loaanis Ntintakis, Dimitrios Chaidas, \& Athanasios Makris. (2013). Design and Development of Innovative Packaging for Agricultural Products. Proscenia Technology, Vol. 8, No. 3, 575-579

Barber, N., Kuo, P. J., Bishop, M., \& Goodman, R. (2012). Measuring psychographics to assess purchase intention and willingness to pay. Journal of Consumer Marketing. https://doi.org/10.1108/07363761211237353

D'Souza, C., Taghian, M., Lamb, P. \& Peretiatkos, P. (2006). Green Products and Corporate Strategy : An Empirical Investigation. Journal of Society and Business Review, 1 (2), 144-157

Fatima, Z. (n.d.). Consumer Attitude and Perception towards Green Products.

Zeqiri, J. \& Hasani, V. V. (2015). Using Factor Analysis Tool to Analyze the Important Packaging Elements that Impact Consumer Buying Behavior. International Journal of Academic Research in Business and Social Sciences, 5(6), 267-276.

Kimaryo, L. (2011). Integrating environmental education in primary school education in Tanzania: teachers' perceptions and teaching practices.

Kumar, P. K., \& Anand, B. (2013). Green Marketing: Theory, Practice, and Strategies. Indian Journal of Marketing, 43(1), 54-56.

Kumar, Y., Shukla, P., Singh, P., Prabhakaran, P. P., Tanwar, V. K., \& Kumar, Y. (2014). Bio- Plastics: A Perfect Tool for Eco-Friendly Food Packaging: A Review. Journal of Food Product Development and Packaging / Year-2014 / (Vol. 1). Retrieved from www.jakraya.com/journal/jfpdp

Noor, N. A. M., Muhammad, A., Kassim, A., Jamil, C. Z. M., Mat, N., Mat, N., \& Salleh, H. S. (2012). Creating Green Consumers: How Environmental Knowledge and Environmental Attitude Lead To Green Purchase Behaviour?. International Journal of Arts \& Sciences, 5(1), 55.

Raja Kumar Kathiravelu, K. K., Beng Hui, C., Chai Boon Hui, B., Lama, N., Tai Seng, W., \& Kumar Moona Haji Mohamed, R. (2014). Youth Perception towards Green Credential Advertisements in a Malaysian context. International Journal of Academic Research in Business and Social Sciences, 4(6), 2222-6990. https://doi.org/10.6007/IJARBSS/v4-i6/940

Salahshour, A.; \& Feiz, D. (2009) The Role of Packaging in Marketing, 1st Edition. Semnan: University of Semnan.

Shuo- Ting Wei, Li-Chen Ou, M. Ronnier Luo, \& John B. Hutchings. (2014). Package Design : Colour Harmony and Comsumer Expectation. International Journal of Design, Vol. 8, No. 3, 1-19.

Suki, N. M. (2013). GREEN AWARENESS EFFECTS ON CONSUMERS' PURCHASING DECISION: SOME INSIGHTS FROM MALAYSIA. IJAPS (Vol. 9). Retrieved from https://pdfs.semanticscholar.org/2ed7/9494c476f1054a9e62576c637e5aa9557d5f.pdf 
INTERNATIONAL JOURNAL OF ACADEMIC RESEARCH IN BUSINESS AND SOCIAL SCIENCES Vol. 8, No. 9, Sept. 2018, E-ISSN: 2222-6990 @ 2018 HRMARS

Yakup, D., \& Sevil, Z. (2011). A Theoretical Approach to Concept of Green Marketing. Interdisciplinary Journal of Contemporary Research in Business (Vol. 3). 